\title{
Cutting the Supply of Climate Injustice*
}

\author{
Peter Newell and Mohamed Adow
}

\begin{abstract}
This article considers the role of activism and politics to restrict the supply of fossil fuels as a key means to prevent further climate injustices. We firstly explore the historical production of climate injustice through extractive economies of colonial control, the accumulation of climate debts, and ongoing patterns of uneven exchange. We develop an account which highlights the relationship between the production, exchange, and consumption of fossil fuels and historical and contemporary inequalities around race, class, and gender which need to be addressed if a meaningful account of climate justice is to take root. We then explore the role of resistance to the expansion of fossil-fuel frontiers and campaigns to leave fossil fuels in the ground with which we are involved. We reflect on their potential role in enabling the power shifts necessary to rebalance energy economies and disrupt incumbent actors as a prerequisite to the achievement of climate justice.
\end{abstract}

Keywords fossil fuels, climate justice, power shift, supply-side, colonialism, climate debt, unequal exchange, resistance, race, class, gender.

\section{Introduction}

Runaway climate change constitutes an unprecedented threat to the prospects of development of the world's poor. This threat comes in the form of impacts on food and water security, 'natural' disasters, extreme weather events, and a wide range of health and environmental stresses associated with a 'hothouse earth' (Steffen et al. 2018). Though some of the worst effects of these changes will be felt in the future, many are already exacerbating and further entrenching existing inequalities and deprivations along the lines of race, class, gender, and other social dynamics.

At the same time, the project of globalising, modernising development driven by extractivism and uneven exchange - and financed by the development industry itself - is one of the key drivers of that change and shows few signs of changing course 
despite growing acknowledgement of the threat the climate crisis poses to efforts to eliminate poverty articulated in the Sustainable Development Goals (SDGs) (Newell forthcoming). Without a sustained effort to disentangle itself from fossil-fuelled development, the development industry is unlikely to play a progressive and transformative role in building a climate-resilient future. This is a critical moment for it to withdraw support for the fossil-fuel economy and the infrastructures which sustain it.

We now need a new approach to addressing this crisis. As the Intergovernmental Panel on Climate Change (IPCC) has pointed out, we need 'transformative systemic change' (IPCC 2018: 40). This is no longer a question of incremental change or narrower forms of 'plug and play' whereby new energy sources or technologies are added to the mix, but all other relations of power and systems of production and exchange remain in place (Newell and Martin 2020). Critical to the success of any such efforts is the need for power shifts to rebalance energy economies as a prerequisite to achieving climate justice (Newell 2021b). This means consciously and deliberately rolling back the power of the fossil-fuel industry over politics.

The power of that lobby is evident in the incongruence between the commitments nations have signed up to under the Paris Agreement and ongoing plans to expand production of fossil fuels. The latest Production Gap report by the United Nations Environment Programme (UNEP) and the Stockholm Environment Institute (SEI), for example, showed that governments are planning to extract 120 per cent more fossil fuels than is compatible with the goals of the Paris Agreement (SEl et al. 2020). For this reason, we seek to address the elephant in the room: the under-acknowledged yet critical need to equitably leave vast swathes of remaining fossil fuels in the ground.

\section{The production of climate injustice}

We suggest here that a more historical, social, and global account of the production of climate justice is needed so as to identify possible intervention points for countering and reversing patterns of climate injustice with a particular focus on supply-side climate policy in contrast to the dominant policy approach to date of regulating demand-side consumption-based emissions. The history of climate change is one of compounding injustices. The wealth of many Western countries was built on the riches and natural resources extracted from their colonial empires, a process that motivated - and in turn was fuelled by - the burning of coal, oil, and gas and vast deforestation. The Industrial Revolution may have produced crowded, smoke-filled cities full of people with chronic health problems, but over time, it ensured that future generations in industrialised economies would grow up in relative privilege compared with people elsewhere, who were often living under colonial rule. The consumption of fossil fuels forms a key pillar, therefore, of global inequality. 


\subsection{Historicising climate injustice in the fossil-fuel economy}

First, regarding the historical production of climate injustice, richer countries not only emit more carbon into the atmosphere per capita than poor countries do, but also their very wealth and stature rest on a century of emissions and environmental degradation (Malm 2016). A growing number of accounts have shown how the wealth from colonial looting financed growing concentrations of fossil-fuelled wealth in colonial powers (Newell 2021a; Nikiforuk 2012). Work on carbon debts, meanwhile, demonstrates the extent of the over-use of the commons by richer states and the disproportionate responsibility they bear to now address the impacts of the pollution generated by the wealth they have extracted (Adow 2020; Simms 2005).

While some aspects of the violence that was intrinsic to colonialism are less visible or flagrantly exercised today, the danger is that technologies of control furnished in the colonial era, such as direct extraction and dispossession of land and livelihoods, are now getting replayed through climate colonialism in the form of green grabs and reducing emissions from deforestation and degradation (REDD) forest projects, for example (Bachram 2004; Fairhead, Leach and Scoones 2012).

Amid this more general account, there is also a need to be more specific about agency and the disproportionate responsibility of the 'polluter elite' and the fossil-fuel majors in particular (Kenner 2019). For example, just six of the largest listed oil and gas companies alone hold reserves that together would use up more than a quarter of the remaining $2^{\circ} \mathrm{C}$ budget and historically speaking, just 90 companies have caused two-thirds of anthropogenic global warming emissions (Heede 2014). Likewise, only about 5 per cent of the world's population collected around 50 per cent of fossil-fuel rents generated between 1970 and 2010 (Kartha, Lazarus and Tempest 2016).

Second, this historical account needs to include a recognition of the racial nature of extractivism. Scholarship on racial capitalism usefully draws attention to the implied racialised hierarchy that characterises the operation of the global economy (Bhattacharyya 2018; Tilley and Shilliam 2018) where standards of protection, duty of care, and enforcement of rights are practised in uneven ways which leave racialised minorities particularly vulnerable to social and environmental injustices (Bullard 2000). This is true of those on the frontlines of more extreme extractivism, as well as through displacement and dispossession, and the dumping of the waste and externalities produced by the accumulation of wealth in richer parts of the world (Agyeman, Bullard and Evans 2003). These racialised hierarchies are also visible in the double standards adopted by richer colonial powers that reject polluting fossil-fuel infrastructures at home but provide financial support for fossil-fuel infrastructures in formerly colonised economies, such as UK government support for gas 
terminals in Mozambique or fracking in Argentina, having banned fracking at home.

When rich nations do invest in poor countries, they end up spending billions of dollars propping up fossil-fuel industries there. A 2018 report by the research and advocacy organisation Oil Change International showed that between 2014 and 2016, '60 per cent of international public aid for energy projects in Africa was spent on fossil fuels - principally through investments in oil and gas infrastructure - with only 18 per cent directed to renewable sources such as wind and solar energy' (OCl 2018: 67).

At the 2020 UK-Africa summit on ties between the UK and African countries, the UK prime minister, Boris Johnson, announced that his country would stop using aid money to fund coal projects abroad, and an official government press release for the event highlighted increased funding for clean energy. But a few days later, it emerged that 90 per cent of the energy deals concluded at the summit were in fact for fossil fuels.

The issue of double standards applies equally to the private sector. Research by Greenpeace and the World Wildlife Fund found that the amount of carbon dioxide production financed by Britain's banks and asset managers is nearly double the UK's annual carbon emissions (Makortoff 2021). Meanwhile, a report on fossil finance by Rainforest Action Network, the Indigenous Environment Network and others found two major UK banks to be in the top 13 largest financers of fossil fuels worldwide, with Barclays Bank alone responsible for US\$145bn of funding over the period 2016-20 (RAN et al. 2021).

Contemporary expressions of deep-seated colonial attitudes which underpin these double standards are not hard to find. At a Pacific Islands Forum in 2019, the chair of that gathering, the former prime minister of Tuvalu, Enele Sopoaga, said he was stunned by Australian prime minister Morrison's remark that Pacific leaders should 'take the money... then shut up about climate change' (Lyons 2019). The degrading insult was made worse by the words of Morrison's deputy, Michael McCormack, who at the time said he was 'annoyed' at the Pacific Islanders 'pointing the finger at Australia' over the climate crisis when in actual fact the islanders would survive 'because many of their workers come here to pick our fruit' (ibid.).

Meanwhile, the UK prime minister, Boris Johnson, stated in a magazine article that: 'the best fate for Africa would be if the old colonial powers, or their citizens, scrambled once again in her direction; on the understanding that this time they will not be asked to feel guilty', reflecting his diagnosis that 'The problem is not that we were once in charge, but that we are not in charge anymore' (Johnson 2016). 


\subsection{Global inequities}

These historical inequities continue to be reflected in vast disparities in emissions and contributions to the production of climate injustice. The contrasts are stark: the United States, with a population of approximately 323 million, emits 5bn metric tonnes of carbon dioxide per year compared to a region such as sub-Saharan Africa which emits a combined total of around $823 \mathrm{~m}$ metric tonnes of carbon dioxide per year from a population of about a billion people (Adow 2020). The figures indicate contrasts that are as huge as twentyfold (ibid.). In the Commonwealth, richer countries such as the UK, Canada, and Australia have high per capita emissions than many other Commonwealth countries in the global South. For instance, a Power Shift Africa (2020: 9) report indicated that 'the UK emits more carbon dioxide per person than 18 Commonwealth countries combined'. In the same report, it was found that Canada and Australia emit more carbon dioxide than 27 Commonwealth nations and 28 Commonwealth countries respectively (ibid.).

Moreover, ongoing global ambitions on the part of the richest countries to expand their fossil-fuel industries imply greater reductions in carbon budgets for poorer countries if overall limits are not to be surpassed. Power Shift Africa (2020) found that richer countries such as Canada, despite their low population, have plans to use up a large part of the remaining global carbon budget. This is notwithstanding the rhetoric from the leadership of these countries. For example, in spite of the promises and commitments from Canadian leadership, if its investment plans are anything to go by, it might end up using a third of the world's remaining carbon budget (ibid.). Trudeau's commitment to a fossil-fuel future was made clear when he said to a group of cheering Texas oilmen: 'No country would find 173 billion barrels of oil in the ground and leave them there' (ibid.: 9). There is a chasm, therefore, between the emissions of the wealthy global North members and Commonwealth countries from the global South that are the most affected by the impacts of climate change.

Furthermore, the post-Covid-19 pandemic economic recovery plans of governments such as the UK, Australia, and Canada are pumping billions of dollars into dirty fossil-fuel industries, effectively rebooting some of the richest economies on the backs of Commonwealth citizens in climate-vulnerable countries. G20 governments have directed more Covid-19 recovery support to fossil-fuel production and consumption than to renewable energy, energy efficiency, and other low-carbon alternatives (US $\$ 233$ bn vs US\$146bn, as of November 2020) (SEl et al. 2020: 20), while a report by Tearfund in June 2021 showed that G7 nations have spent US\$190bn on coal, oil, and gas compared to just US\$147bn on clean energy since the start of the pandemic (Dufour et al. 2021).

Underpinning this disparity is extractivism and ecologically uneven exchange. This takes a number of forms: from virtual 
carbon (the outsourcing of the most polluting parts of the production process) to the dangers of renewable extractivism and the intensification of mining. For example, minerals such as lithium and cobalt are mined to support transitions to electrification of the energy system in wealthier parts of the world (Sovacool et al. 2019).

Richer countries are also able to make use of a range of spatial and temporal fixes (Harvey 1981) through green grabs, carbon trading, and the like to displace responsibility for the climate crises onto poorer groups, particularly in the global South (Newell 2021b). Though some of these interactions are privately driven, many are reinforced by global institutions of trade, aid, and finance, and the use of state power. They produce lock-in through a particular model of dependency, export of fossil fuels, and private-led power sector reform (Tellam 2000; Newell 2021b). This ideology and set of institutional lock-ins perpetuated by the development industry needs to change if we are to address the roots of climate injustice.

\subsection{The production of social injustices in the fossil-fuel economy}

As well as a historical account of the injustices associated with today's fossil-fuel economy which necessarily form the starting point for campaigns for climate and environmental justice, we also need a more social account. Climate change exacerbates existing inequalities. Between 1961 and 2000, emissions from poorer countries caused US\$740bn worth of damage to wealthier countries, whereas emissions from richer countries caused US\$2.3tn worth of damage to poorer ones.

In poorer countries, the impacts of climate change have extended beyond economic damage. In these regions, climate change is hindering socioeconomic progress and people's wellbeing. In sub-Saharan Africa, frequent extreme weather events are affecting people's livelihoods, thus impeding economic growth. It is noteworthy that despite sub-Saharan Africa having contributed the least to the global energy-related emissions, it is having to pay the highest economic price for emissions from richer countries. Sub-Saharan African countries such as Burkina Faso, Niger, and Sudan have had a significant reduction in their per capita gross domestic products as a result of climate impacts (Meseret 2020; Diffenbaugh and Burke 2019; Adow 2020).

Social relations of race, class, and gender interact with these economic and environmental injustices, exacerbating existing vulnerabilities, exclusions (from resources and their governance) and inequalities (Newell 2005, 2021a). A large number of studies on environmental justice, environmental racism, and from feminist political ecology explore these dynamics (Bullard 2000; Rocheleau, Thomas-Slayter and Wangari 1996; Sikor and Newell 2014). These cover not just direct sites of extraction of fossil fuels, but also their processing in petro-chemical complexes in places 
such as 'Cancer Alley' in Louisiana in the US, for example (Wright 2005). The breadth of social, human, and environmental impacts produced along the fossil-fuel supply chain, from hazardous working conditions and local pollution at the source of production, to marine pollution in the transport of fossil fuels around the world, to the health impacts of their combustion in housing and transport systems, creates, at the same time, incentives for intersectional alliances. These can be between movements as diverse as labour, indigenous groups, women's groups, and environmental movements with different reasons for fighting a common battle against the largest driver of climate injustice.

\section{Contesting climate injustice}

Climate injustices will continue to be perpetuated as long as the fossil-fuel economy lasts. An urgent priority for social movements, non-governmental organisations, and governments, therefore, is to disassemble that economy in as fair a way as possible as part of a just transition. There are a number of ways of doing this.

First, there are campaigns to withdraw financial support to fossil fuels. This means challenging the lending practices of bodies such as the World Bank, as well as bilaterals and governments through advocacy on fossil-fuel finance. The issue is that despite the negotiation of the Paris Agreement in 2015, total multilateral development bank finance for oil and gas exploration more than doubled from 2015 to 2016, from US\$1.05bn to US\$2.15bn. The World Bank Group, the European Investment Bank (EIB), and the Asian Development Bank were the largest financiers of fossil fuels in 2016. At the same time, renewable energy still made up less than a third of multilateral development bank energy finance (OCl 2018).

There have been a number of successes in this regard, including commitments from the EIB to discontinue financial support to fossil fuels and from the UK government to end the use of export finance for fossil fuels, though much work remains to be done and such commitments often come with caveats and exemptions and need to be situated in the broader landscape of financial flows described below. Some campaigns have exposed the inconsistencies in government policy between climate objectives and the ongoing pursuit of fossil-fuel extraction, such as the campaign aimed at the activities of specific government agencies in the case of the 'paid to pollute' campaign targeted at the UK's oil and gas authority which has a mandate to expand fossil-fuel extraction. This included a judicial review launched by the campaign group Uplift exposing the fact that since signing the Paris Agreement in 2016, the UK government has paid £3.2bn of public money to North Sea oil and gas companies.'

With regard to the private sector, fossil-fuel divestment movements have played a critical role in encouraging institutional investors - universities, pension funds, and others - to divest from fossil fuels (Bergman 2018). Thanks largely to the climate 
advocacy group 350.org joining forces with the student activists, to date, 688 institutions and 58,399 individuals across 76 countries have committed to divest from fossil-fuel companies. By 2018, the fossil-fuel divestment movement marked the 1,000th divestment in what has become by far the largest anti-corporate campaign of its kind, bringing the total size of portfolios and endowments in the campaign to just under US\$8tn (£6.4tn) (McKibben 2018).

Second, there is more politically focused work to disrupt incumbent control over the political system. This aims to challenge the political influence of the polluter elite (and not just their investment power or direct emissions associated with high carbon living) (Kenner 2019) through exposure work and lobbying for greater regulation and transparency around lobbying, representation, party donations, and the like. It focuses on cleaning up governance with regard to party donations, revolving doors, internships, and access to key decision-making bodies (Newell and Martin 2020).

The work of activist organisations such as the Corporate European Observatory and DeSmog is particularly important here. To give an indication of the scale of the challenge, by the close of 2019, 134 members in US Congress and their spouses owned as much as US\$92.7m worth of stock in fossil-fuel companies and mutual funds (Kotch 2020). Fossil-fuel industry political giving outdoes renewables 13 to 1 in the US, with the fossil-fuel industry spending at least US\$359m in the 2018 mid-term cycle for federal campaign donations and lobbying (Kirk 2020). Globally, according to one recent analysis, among 350 companies that represent around 100 leading industry groups, over 90 per cent have at least one membership in an industry association with lobbying practices that undermine the Paris Agreement (InfluenceMap 2021).

There is also a revolving door between high-level offices in government and fossil-fuel industries that needs to be stopped if the injustices associated with the expansion of fossil-fuel frontiers are to be brought to an end. For example, as Newell and Martin show, 'nearly 90 per cent of people leaving the UK's Department of Energy and Climate Change took up jobs in the energy sector, including six former energy ministers' (Newell and Martin 2020: 24). Some hold these positions at the same time. While serving as Minister of State for Energy, Charles Hendry secured $£ 3,333$ a day as a consultant for Vitol, the world's biggest oil trader handling 270m tonnes of oil in 2016.

However, the door swings the other way too, with private sector actors securing key roles in government. For example, Lord Browne, former CEO of BP, was made 'lead non-executive director' at the Cabinet Office by former prime minister David Cameron in 2010. Lord Browne was also chair of fracking company Cuadrilla at the time and made clear his intention to do 
'whatever it takes' to promote shale gas (Cato 2018). Strategies need to focus on clearer party financing rules, registries of politicians' interests, boards of companies they sit on, the corresponding restrictions on which committees they sit on, and policymaking processes they are part of when there are such obvious conflicts of interest.

Third, in recent years, litigation has emerged against individual fossil-fuel projects (e.g. coal mines in Australia and the UK, and oil and gas pipelines in the US), against individual fossil-fuel companies (Shell in the Netherlands, Total in France, ExxonMobil in the US), and against carbon majors as a whole (in the Philippines). The recent case against Shell is perhaps one of the most telling examples: the Dutch court ordered Shell to achieve a specific emission reduction target along its entire supply chain, effectively suggesting that the company had to cut back production (van Asselt et al. 2021).

Loss and damage represent another important frontier in this battle (Toussaint 2021). Yet, despite the existence of the Warsaw mechanism on loss and damage, at the Madrid climate summit, the US, with Russia's support, ruled out agreeing to and implementing a concrete plan to increase financing for loss and damage. Other rich countries, including Australia, Japan, and some member states of the EU, sheepishly followed suit, leaving vulnerable countries without the help promised to them in 2013. Nevertheless, moves to strengthen loss and damage provisions might provide further impetus towards leaving fossil fuels in the ground (ibid.).

Fourth, and more directly, we have seen over the last few years, a growing wave of supply-side policy activism supporting countries and cities to adopt a range of policies to leave fossil fuels in the ground, as well as more broadly around the idea of a Fossil Fuel Non-Proliferation Treaty or other multilateral alternative to equitably leave remaining swathes of fossil fuels in the ground (Newell and Simms 2019; Burke and Fishel 2020). Gaulin and Le Billon (2020), drawing on a fossil-fuel-cuts database, found that 1,302 initiatives were implemented between 1988 and 2017 in 106 countries across seven major types of supply-side approaches. SAFE Cities, for example, is a growing network of cities, counties, and other communities that Stand Against Fossil Fuel Expansion (55 so far) and a number of key cities including Vancouver, Barcelona, Sydney, and Los Angeles, as well as the Australian Capital Territory, have endorsed the idea of a Fossil Fuel Non-Proliferation Treaty. These efforts help to socialise the idea of production limits on fossil fuels.

Finally, and critically, there is widespread resistance to new fossil-fuel projects (Temper et al. 2020; Carter and McKenzie 2020). This is a rising, but not altogether new, phenomena with resistance to the expansion of fossil-fuel frontiers in the global 
North and South going back decades, even if climate was not the primary driver (Princen, Manno and Martin 2015). Temper et al. (2020) find, nevertheless, that over a quarter of fossil-fuel projects encountering social resistance have been cancelled, suspended, or delayed. The example of the proposed coal plant on the United Nations Educational, Scientific and Cultural Organization World Heritage site of Lamu off the Kenyan coast is an example of a victory for climate justice. A group of dedicated local campaigners, Save Lamu and DeCOALonise, managed to fend off the financial interests of investors General Motors and the Industrial and Commercial Bank of China.

Despite this resistance, many fossil-fuel companies are keen to see fossil-fuel expansion across Africa, from Ghana to Kenya and Mozambique, despite the abundance of renewable energy (Bos and Gupta 2016; Phillips 2019; Newell and Phillips 2016) and the geopolitical risks associated with further lock-in to fossil-fuel pathways (Gupta and Chu 2018). The role of Chinese finance in supporting investments in fossil fuels is especially notable here (Power et al. 2016; Shen and Power 2017) and presents particular challenges for activists where normal channels of influence are harder to pursue with state development banks based in non-democratic societies (Gore 2017).

This activism does not exist in a vacuum, therefore, but rather seeks to magnify and accelerate emergent political and social tipping points. These include a confluence of the falling price of renewables and availability of battery storage technologies, bolder government commitments including the adoption of supply-side policies by first movers such as Costa Rica, Belize, New Zealand, Denmark, and France, as well as coalitions building on the Powering Past Coal Alliance (Jewell et al. 2019). Another tipping point is the diminishing licence to operate of fossil-fuel companies contested by social movements across a range of policy arenas and cultural spheres, combined with investor concerns about stranded assets.

It is also important to note that some of this resistance is being articulated around novel articulations of intersectional, multi-generational, multicultural indigenous-led movements seeking to contest climate injustices, the criminalisation of land protection, and expressing forms of anti-colonial solidarity (Spiegel 2021a, 2021b). What this activism highlights and seeks to contest are the ways in which indigenous people are particularly affected by the injustices of fossil fuels (Jonasson 2019; Gilio-Whitaker 2019). In these instances, fossil fuels happen to be the campaign focus, but the activism is aimed at contesting, dismantling, and decolonising the very power structures, hierarchies, and failures of recognition which permit and enable these injustices to take place in the first place, routinely distributing the greatest costs of fossil-fuel expansion to poorer classes and to people of colour (Bullard 2000; Newell 2005). 


\section{Conclusions}

We have briefly explored here the growing momentum around a diverse range of strategies aimed at keeping fossil fuels in the ground. We have argued that their adoption and wider uptake are crucial to reverse centuries of injustices produced by the fossil-fuel economy, of which climate injustices are just the latest manifestation.

The onus is clearly on rich countries to take a lead in addressing these climate injustices. For reasons of lack of resources, capacity, or policy autonomy, many countries in the global South are trapped by these fossil-fuelled dependencies, sedimented over centuries. For many poor countries awash with problems, including insufficient energy production, following the fossil-fuel-laden course that wealthy nations took is the path of least resistance and is particularly attractive for elites in those countries because of the opportunities for rent-seeking that fossil fuels enable. Yet there is an opportunity to chart a different course, but also work to do in order to ensure that old injustices are not perpetuated, or newer ones created.

There is no one theory of change which will underpin the success of movements against climate injustices. We need to mobilise all pressure points to challenge fossil-fuel incumbency. This brings different challenges in different settings and depends a great deal on degrees of democratic space, the nature of state power, and the degree of positive engagement by business and civil society actors. The risks for many environmental defenders of confronting the fossil-fuel industry are very high (Global Witness 2017).

Then again, so are the risks of allowing runaway climate change and enabling the fossil-fuel industries to further tighten their grip on economies by locking in fossil-fuel use for decades to come. A key challenge is confronting and reducing incumbent power over future energy pathways when the interests of the state and fossil capital are so closely aligned, given the revenues, tax, and employment associated with the sector in both its state-owned and private configurations. This means that states are often willing to use their monopoly on the use of force to crush protest and dissent targeted at the fossil-fuel complex (Brock et al. 2018).

This is a critical moment in the history of activism against climate injustice. As desperation mounts about the scale of the challenge and the speed of responses needed, social movements can spend all of their time fire-fighting proposals to achieve net-zero that often include regressive solutions for many of the world's poorest people. But they also need to keep focused on the elephant in the room: the obvious need to turn off the tap of finance for fossil fuels and to equitably leave large swathes of fossil fuels in the ground as the greatest single thing that can be done to prevent further climate injustices. 


\section{Authors}

Peter Newell is a Professor of International Relations at the University of Sussex and co-founder and research director of the Rapid Transition Alliance. He sits on the Board of Directors of Greenpeace UK. His recent research focuses on the political economy of low-carbon energy transitions. Peter has worked at the universities of Sussex, Oxford, Warwick, and East Anglia in the UK and FLACSO Argentina. His single and co-authored books include Climate for Change (2000, Cambridge University Press (CUP)), Governing Climate Change (2010, Routledge), Globalization and the Environment (2012, Polity), Climate Capitalism (2012, CUP), Transnational Climate Change Governance (2014, CUP), Global Green Politics (2019, CUP), and Power Shift: The Global Political Economy of Energy Transitions (2021, CUP).

Mohamed Adow is the Founding Director of Power Shift Africa. $\mathrm{He}$ is also the Africa expert advisor for Africa for the Climate Vulnerable Forum (CVF). For almost two decades Mohamed has been deeply involved in international climate and energy issues, including advising states in multilateral negotiations on climate change, developing policies and programmes. From 2008 to 2019, he led Christian Aid's global climate policy and advocacy work specialising in developing countries issues and supporting the organisation's climate policy and advocacy work across the world. During this period, he served as the head of the delegation of Christian Aid to the United Nations Framework Convention on Climate Change (UNFCCC), the Montreal Protocol, and several other multilateral environmental negotiations, and engaged and influenced governments and other stakeholders in favour of the world's poor people and countries.

\section{Notes}

* We are grateful for the reviews of this article by external referees and the issue editors of this IDS Bulletin.

1 Paid to Pollute.

\section{References}

Adow, M. (2020) 'The Climate Debt: What the West Owes the Rest', Foreign Affairs, May/June (accessed 14 October 2021)

Agyeman, J.; Bullard, R.D. and Evans, B. (eds) (2003) Just Sustainabilities: Development in an Unequal World, Cambridge MA: MIT Press

Bachram, H. (2004) 'Climate Fraud and Carbon Colonialism: The New Trade in Greenhouse Gases', Capitalism Nature Socialism 15.4: 5-20

Bergman, N. (2018) 'Impacts of the Fossil Fuel Divestment Movement: Effects on Finance, Policy and Public Discourse', Sustainability 10.7: 2529

Bhattacharyya, G. (2018) Rethinking Racial Capitalism: Questions of Reproduction and Survival, London: Rowman \& Littlefield 
Bos, K. and Gupta, J. (2016) 'Inclusive Development, Oil Extraction and Climate Change: A Multilevel Analysis of Kenya', International Journal of Sustainable Development and World Ecology 23.6: 482-92

Brock, A. et al. (2018) 'Fracking Democracy, Criminalising Dissent', The Ecologist, 18 October

Bullard, R.D. (2000) Dumping in Dixie: Race, Class, and Environmental Quality, New York NY: Routledge

Burke, A. and Fishel, S. (2020) 'A Coal Elimination Treaty 2030: Fast Tracking Climate Change Mitigation, Global Health and Security', Earth System Governance 3: 100046

Carter, A.V. and McKenzie, J. (2020) 'Amplifying "Keep It in the Ground" First-Movers: Toward a Comparative Framework', Society and Natural Resources 33.11: 1339-58

Cato, M.C. (2018) 'Revealed: The Revolving Door Between Westminster and the Fossil Fuel Industry', Left Foot Forward, 8 May (accessed 14 October 2021)

Diffenbaugh, N.S. and Burke, M. (2019) 'Global Warming Has Increased Global Economic Inequality', Proceedings of the National Academy of Science of the United States of America 116.20: 9808-13 (accessed 14 October 2021)

Dufour, L.; Moerenhout, T.; Picciariello, A. and Beedell, E. (2021) Cleaning Up Their Act? G7 Fossil Fuel Investments in a Time of Green Recovery, Teddington: Tearfund

Fairhead, J.; Leach, M. and Scoones, I. (2012) 'Green Grabbing: A New Appropriation of Nature?', Journal of Peasant Studies 39.2: 237-61

Gaulin, N. and Le Billon, P. (2020) 'Climate Change and Fossil Fuel Production Cuts: Assessing Global Supply-Side Constraints and Policy Implications', Climate Policy 20.8: 888-901

Gilio-Whitaker, D. (2019) As Long as Grass Grows: The Indigenous Fight for Environmental Justice, from Colonization to Standing Rock, Boston MA: Beacon Press

Global Witness (2017) Defenders of the Earth, London: Global Witness

Gore, C.D. (2017) Electricity in Africa: The Politics of Transformation in Uganda, Woodbridge: James Currey

Gupta, J. and Chu, E. (2018) 'Inclusive Development and Climate Change: The Geopolitics of Fossil Fuel Risks in Developing Countries', African and Asian Studies 17.1-2: 90-114

Harvey, D. (1981) 'The Spatial Fix - Hegel, von Thünen, and Marx', Antipode 13.3: 1-12

Heede, R. (2014) 'Tracing Anthropogenic Carbon Dioxide and Methane Emissions to Fossil Fuel and Cement Producers, 1854-2010', Climatic Change 122.1-2: 229-41

InfluenceMap (2021) The CA100+ Target Companies: Scoring and Analysis of Climate Lobbying (accessed 14 October 2021)

IPCC (2018) Global Warming of $1.5^{\circ} \mathrm{C}$ : An IPCC Special Report on the Impacts of Global Warming of $1.5^{\circ} \mathrm{C}$ above Pre-industrial Levels and Related Global Greenhouse Gas Emission Pathways, Geneva: International Panel on Climate Change 
Jewell, J.; Vinichenko, V.; Nacke, L. and Cherp, A. (2019) 'Prospects for Powering Past Coal', Nature Climate Change 9: 592-7 Johnson, B. (2016) 'Africa is a Mess but We Can't Blame

Colonialism', The Spectator, 14 July (accessed 14 October 2021)

Jonasson, M.E. et al. (2019) 'Oil Pipelines and Food Sovereignty:

Threat to Health Equity for Indigenous Communities', Journal of Public Health Policy 40.4: 504-17

Kartha, S.; Lazarus, M. and Tempest, K. (2016) Fossil Fuel Production in a $2^{\circ} \mathrm{C}$ World: The Equity Implications of a Diminishing Carbon Budget, Stockholm: Stockholm Environment Institute

Kenner, D. (2019) Carbon Inequality: The Role of the Richest in Climate Change, Oxon: Routledge

Kirk, K. (2020) 'Fossil Fuel Political Giving Outdistances Renewables 13 to One', Yale Climate Connections, 6 January (accessed 28 February 2021)

Kotch, A. (2020) 'Members of Congress Own Up to \$93 Million in Fossil Fuel Stocks', Sludge, 3 January (accessed 28 February 2021)

Lyons, K. (2019) 'Former Tuvalu PM Says He was "Stunned" by Scott Morrison's Behaviour at Pacific Islands Forum', The Guardian, 23 October (accessed 14 October 2021)

Makortoff, K. (2021) 'British Banks Finance 805m Tonnes of CO2 Production a Year', The Guardian, 25 May (accessed 14 October 2021)

Malm, A. (2016) Fossil Capital: The Rise of Steam Power and the Roots of Global Warming, London: Verso

McKibben, B. (2018) 'At Last, Divestment Is Hitting the Fossil Fuel Industry Where It Hurts', The Guardian, 16 September (accessed 14 October 2021)

Meseret, E. (2020) 'Africa Shouldn't Need to Beg for Climate Aid: Bank President', AP News, 11 February laccessed 14 October 2021)

Newell, P. (forthcoming) 'Climate Change and Development: A Tale of Two Crises', in M. Delancio, P. Nemiña and D. Tussie (eds), Handbook on the Politics of International Development, Cheltenham: Edward Elgar

Newell, P. (2021a) 'Race and the Politics of Energy Transitions', Energy Research and Social Science 71: 101839

Newell, P. (2021b) Power Shift: The Global Political Economy of Energy Transitions, Cambridge: Cambridge University Press

Newell, P. (2005) 'Race, Class and the Global Politics of Environmental Inequality', Global Environmental Politics 5.3: 70-94

Newell, P. and Martin, A. (2020) The Role of the State in the Politics of Disruption and Acceleration, Working Paper, London: Climate KIC

Newell, P. and Phillips, J. (2016) 'Neoliberal Energy Transitions in the South: Kenyan Experiences', Geoforum 74: 39-48

Newell, P. and Simms, A. (2019) 'Towards a Fossil Fuel Non-Proliferation Treaty', Climate Policy 20.8: 1043-54 
Nikiforuk, A. (2012) The Energy of Slaves: Oil and the New Servitude, Vancouver: Greystone Books

OCI (2018) Cross Purposes: After Paris, Multilateral Development Banks Still Funding Billions in Fossil Fuels, Washington DC: Oil Change International

Phillips, J. (2019) 'Who's in Charge of Sino-African Resource Politics? Situating African State Agency in Ghana', African Affairs 118.470: 101-24

Power, M. et al. (2016) 'The Political Economy of Energy Transitions in Mozambique and South Africa: The Role of the Rising Powers', Energy Research and Social Science 17: 10-19

Power Shift Africa (2020) Climate Change Inequality in the Commonwealth: How the UK, Canada and Australia are Endangering Africa, Nairobi: Power Shift Africa

Princen, T.; Manno, J.P. and Martin, P. (eds) (2015) Ending the Fossil Fuel Era, Cambridge MA: MIT Press

RAN et al. (2021) Banking on Climate Chaos: Fossil Fuel Finance

Report 2021, Rainforest Action Network, BankTrack, Indigenous Environmental Network, Oil Change International, Reclaim Finance and the Sierra Club (accessed 22 October 2021)

Rocheleau, D.; Thomas-Slayter, B. and Wangari, E. (eds) (1996) Feminist Political Ecology: Global Issues and Local Experience, Oxon: Routledge

SEl, IISD, ODI, E3G and UNEP (2020) The Production Gap: 2020

Report, Stockholm Environment Institute, International Institute for Sustainable Development, Overseas Development Institute, E3G and the United Nations Environment Programme (accessed 22 October 2021)

Shen, W. and Power, M. (2017) 'Africa and the Export of China's Clean Energy Revolution', Third World Quarterly 38.3: 678-97

Sikor, T. and Newell, P. (2014) 'Globalizing Environmental Justice?', Geoforum 54: 151-57

Simms, A. (2005) Ecological Debt: The Health of the Planet and the Wealth of Nations, London: Pluto Press

Sovacool, B.K.; Martiskainen, M.; Hook, A. and Baker L. (2019) 'Decarbonization and its Discontents: A Critical Energy Justice Perspective on Four Low-Carbon Transitions', Climatic Change 155.4: 581-619

Spiegel, S.J. (2021a) 'Climate Injustice, Criminalisation of Land Protection and Anti-Colonial Solidarity: Courtroom Ethnography in an Age of Fossil Fuel Violence', Political Geography 84: 102298

Spiegel, S.J. (2021b) 'Fossil Fuel Violence and Visual Practices on Indigenous Land: Watching, Witnessing and Resisting Settler-Colonial Injustices', Energy Research and Social Science 79: 102189

Steffen, W. et al. (2018) 'Trajectories of the Earth System in the Anthropocene', Proceedings of the National Academy of Sciences 115.33: 8252-59

Tellam, I. (ed.) (2000) Fuel for Change: World Bank Energy Policy Rhetoric vs Reality, London: Zed Books 
Temper, L. et al. (2020) 'Movements Shaping Climate Futures: A Systematic Mapping of Protests Against Fossil Fuel and Low-Carbon Energy Projects', Environmental Research Letters 15.12: 123004

Tilley, L. and Shilliam, R. (2018) 'Raced Markets: An Introduction', New Political Economy 23.5: 534-43

Toussaint, P. (2021) 'Loss and Damage and Climate Litigation: The Case for Greater Interlinkage', Review of European, Comparative and International Environmental Law 30.1: 16-33 van Asselt, H.; Kulovesi, K.; Rajavuori, M. and Savaresi, A. (2021) Shell-Shocked: A Watershed Moment for Climate Litigation against Fossil Fuel Companies, The Center for Climate Change, Energy and Environmental Law blog, 28 May (accessed 18 October 2021)

Wright, B. (2005) 'Living and Dying in Louisiana's "Cancer Alley"', in R.D. Bullard (ed.), The Quest for Environmental Justice: Human Rights and the Politics of Pollution, San Francisco CA: Sierra Club Books 